\title{
PUBLIC HEALTH ETHICS: TOWARDS A RESEARCH AGENDA
}

\begin{abstract}
Alison Thompson, Ann Robertson, Ross Upshur*
Abstract: Public health ethics, as distinct from clinical/medical bioethics, is an emerging field of study in academic settings. As part of a larger effort to address what the conceptual and content boundaries of this field are, or ought to be, a group at the University of Toronto hosted an international working symposium to discuss and outline a research agenda for public health ethics.

The symposium, which took place in May 2002, was organized into four major areas of ethical concern central to public health: individual rights and the common good; risk and precaution; surveillance and regulation; and social justice and global health equity. This paper will provide an overview of some of the main themes and issues that emerged from the key papers that were developed from the symposium and discuss their importance in the emerging field of public health ethics.

Significant issues were identified, such as the importance of distinguishing public health ethics from traditional bioethics; the development of the notion of common interests; broad definitions of public health, that include upstream sources of health inequities, and an understanding of the theoretical landscape from which public health ethics has emerged.
\end{abstract}

Key words: Public health, public health ethics, rights, global health equity, social justice

\section{ÉTICA EN SALUD PÚBLICA: HACIA UNA AGENDA DE INVESTIGACIÓN}

Resumen: La ética en salud pública, como distinta de la bioética clínica/médica, es un campo de estudio emergente en el ámbito académico. Como parte de un mayor esfuerzo para abordar el contenido y los límites que este campo tiene o debiera tener, un grupo de la Universidad de Toronto realizó un Simposio Internacional con el fin de discutir y definir una agenda de investigación para la ética en salud pública.

El Simposio, realizado en mayo de 2002, fue organizado en torno a cuatro mayores áreas de preocupación ética sobre salud pública: derechos individuales y bien común; riesgos y precaución; vigilancia y regulación; y justicia social y equidad en la salud global. Este artículo proveerá un panorama de algunos de los principales temas y tópicos que emergieron de los artículos clave desarrollados para el simposio y discutirá su importancia para el emergente campo de la ética de la salud pública.

Temas significativos fueron identificados, tales como la importancia de distinguir la ética en salud pública de la bioética tradicional; el desarrollo de la noción de intereses comunes; amplias definiciones de salud pública, que incluyen las fuentes de las inequidades en salud, y una comprensión del campo teórico desde el cual ha emergido la ética en salud pública.

Palabras clave: Salud pública, ética en salud pública, derechos, equidad en la salud global, justicia social

\section{ÉTICA NA SAÚDE PÚBLICA: EM DIREÇÃO A UM TEMÁRIO DE PESQUISAS}

Resumo: A ética na saúde pública, como diferente da bioética clínica/médica, é um campo do estudo emergente na área acadêmica. Segundo uma parte de um maior esforço para abordar o conteúdo e os limites que esse campo tem ou deve ter, um grupo da Universidade de Toronto levou a cabo um Simpósio Internacional para tratar e definir um programa da pesquisa para a ética na saúde pública.

O Simpósio, levado a cabo em maio de 2002, organizou-se ao redor de quatro maiores áreas da inquietude ética pela saúde pública: direitos individuais e bem comun; riscos e a precaução; a vigilância e regulamentação; e a justiça social e a equidade na saúde global. Esse artigo conterá um panorama com alguns dos temas principais que originan-se dos artigos chave desenvolvidos para o simpósio e debatera e tratará sua importância para o campo emergente da ética da saúde pública.

Temas significativos identificaram-se, como a importância de distinguir a ética na saúde pública da bioética tradicional; o desenvolvimento da noção de juros comuns; definições amplas de saúde pública, que incluem as fontes das inequidades na saúde, e uma compreensão da estrutura teórica do que tem surgido a ética na saúde pública.

Palavras chave: Saúde pública, ética na saúde pública, direito, equidade na saúde global, justiça social

* Department of Public Health Sciences \& Joint Centre for Bioethics, University of Toronto, Canada.

Correspondence: a.thompson@utoronto.ca 


\section{Introduction: Rationale for Symposium}

Public health ethics represents an emerging domain of scholarly investigation and discussion. Some, like Dan Beauchamp(1), would argue that public health is fundamentally an ethical enterprise while others, like Simon Szreter(2), would argue that public health, with its origins in the public health reforms of the late 19th Century, has historically been concerned with ethics. However, the development of public health ethics as a field of scholarship is a recent phenomenon unlike the more established field of bioethics.

Since its inception midway through the last century, the field of bioethics has focused on ethical issues pertaining to the practice of medicine and medical research. Consequently, bioethics as a discipline has focused almost exclusively on individualistic concerns, primarily the development of notions of patient autonomy. This is understandable, given the origins of bioethics in the Nuremberg Trials, the Tuskegee Syphilis study and patients' rights movements in the 1960s(3). Indeed, Onora O’Neill has argued that bioethics has been "damagingly preoccupied" with not only the autonomy of individual patients but also with the requirements for justice within, but not between, states(4). As a consequence, public health ethics has been largely neglected.

However, this is beginning to change, and an emerging literature is beginning to conceptualise the scope and central features of the field of public health ethics(3, 5-9). Among other things, the advent of the new genetics, and threats of new global pandemics are drawing attention to the need for research into public health ethics. In Canada in particular, there have been a number of public health "crises" that have indicated a need for an articulated public health ethics. For example, in May 2000 in the town of Walkerton, Ontario, a water- borne e-coli outbreak resulting from inadequate health protection measures was responsible for seven deaths and the infection of almost half of the town's population. The recent SARS outbreak also highlighted the lack of preparation of public health authorities for major infectious disease threats. A major commission has recommended sweeping changes to the governance, legal structure, and training and practice of public health in Canada(10). The use of quarantine, and other restrictive means of disease control in Canada and elsewhere for the control of SARS raised the issue of the appropriate scope and limitation of individual liberty by public health authorities for the control of disease. The variable means by which public health exercised its authority in response to SARS underscores the need for sustained international dialogue on the ethical aspects of disease control and their relation to ethical norms and human rights standards. There is also a growing acknowledgement of the need for action with respect to the enormous health inequities both within and between nations. What is clear from these cases is that the existing frameworks and tools developed by bioethicists are not easily adapted to deal with ethical issues in public health, nor is it appropriate to attempt to do so, given the individualistic focus of much of bioethics.

In order to address the need for research in public health ethics, a group at the University of Toronto organised an international symposium on Public Health Ethics in May 2002. The purpose of the international symposium was to bring together eminent scholars and public policy figures to discuss what research into public health ethics will be required in order to be able to deal with ethical issues arising from factors such as environmental disasters, new infectious disease epidemics (this was one year before SARS), and global biotechnological developments. 
The central focus of this symposium was twofold:

1) To articulate and conceptualise the field of public health ethics as opposed to addressing specific issues arising from the practice of public health, i.e. it dealt with the ethics in public health, rather than the ethics of public health

2) To identify a research agenda for public health ethics that would be of use to scholars, policy-makers and the community.

The symposium was organized around four major themes that the organizing committee saw as characterizing the fundamental ethical domains in public health practice and policy:

- Risk and precaution

- Surveillance and regulation

- Individual rights and the common good

- Social justice/global health equity

The subsequent papers in this issue that are products of this symposium touch on all of these central themes. While the authors sometimes disagree, they lead us to a better understanding of the inherent tensions and problems that will need to be addressed further as public health ethics emerges as an important new field of study.

\section{Overview of Symposium Proceedings}

Jennings' article, "Frameworks for public health," is an appropriate introduction to the rest of the articles that were developed from the symposium. He argues for a better understanding of the ethical and political landscape in which public health controversies and social conflicts are played out, before attempting to develop new ethical discourses in public health ethics. He describes a framework that includes different types of applied ethical discourse, and argues that one type, namely critical ethics, should be prioritized.

It may be that understanding the "normative cultural and ideological context" from which public health has emerged, and in which it is practiced, will help us to understand why public health ethics differs from traditional bioethics. It also will help to show how deeply imbued with normative issues the practice of public health is, and how the role of public normative justification is central. While Jennings' article attempts to map the theoretical terrain of public health in the context of the United States, much of what he argues is applicable, with slight differences, to the industrialized West. As Benatar's paper will show, the challenges facing those in global public health have many of their origins in the ethical and political traditions of liberalism described by Jennings.

While he acknowledges that it is not possible to map ethical theories onto political theories, and vice-versa, Jennings' attempt to show how these two crucially important theoretical bodies influence the thinking of the other demonstrates how patterns of justification can be drawn each from the other. Ultimately, this is important, for while there may not be much fundamental disagreement over values and principles, the most effective means to formulate policy is a source of disagreement. Thus the issues of justice, justification and social legitimacy are central in public health, especially as they pertain to policy making. Jennings uses some interesting examples to illustrate this, such as risk reduction, and health promotion and disease prevention.

Jennings goes on to describe four different rhetorics or styles of ethical discourse found in public health. They are: professional ethics, 
advocacy ethics, applied ethics, and critical ethics. While he claims that advocacy ethics, in which social goals and reforms are championed, is the most lively area of public health ethics, Jennings argues that it is critical ethics where the most crucial work needs to be done. In critical ethics, larger social values and historical trends are brought to bear on the actual institutional arrangements and prevailing structures of public health, encouraging us to see it as a truly public or civic endeavor.

Of course, one of the most important aspects of civil society is its legal system. Gostin's article attempts to demonstrate the relationship between public health ethics, law and human rights. He then provides a framework for systematically evaluating public health policies that draws on each of these important and overlapping fields. In this way, he believes that the trade-off between public health and civil liberties can be reconciled.

Gostin begins by describing what constitutes public health, and then goes on to describe the field of public health ethics. He identifies ways that public health ethics can offer direction on 1) issues pertaining to the profession and practice of the profession; 2) the moral weight and value of the community's health and well being; 3) prevalent themes and dilemmas of public health and its practice; 4) the role of advocacy in public health.

Public health law is important to consider because it is a tool in public health that can influence norms for healthy behavior, identify and deal with health threats, and set and enforce certain standards. Gostin argues that the most important social debates concerning the public's health take place in legal fora, that is, legislatures, courts and administrative agencies. The language of law is also the language used in these debates, i.e., rights, duties and justice.
Not only is law a tool used to achieve health for populations, but it also regulates the "agents of behavioral change," for example, by improving safety standards for manufacturing. It also alters the physical environment by providing standards for builders and business to adhere to, as well as by providing protection to the natural environment.

Gostin argues that the notion of human rights has profoundly influenced the field of public health. He describes the interface of human rights and public health: public health policies can violate human rights; human rights violations can hurt the public's health; and, lastly, policies that promote both human rights and the public's health have positive outcomes for individuals and populations. Quite apart from its formal legal use, one of the key ways that the language of human rights is used is aspirational, or rhetorical.

One of the chief normative concerns in public health is the question of how society ought to decide when to limit individual and economic interests and freedom in order to protect the public's health. In his paper, Gostin offers up some key factors for consideration when determining whether interventions of this nature ought to be undertaken. They pertain to risk assessment, demonstrable effectiveness, economic cost, human rights burdens and fairness. Gostin argues that when thinking about each of these factors, examination of the principles and values emerging from public health ethics, law and human rights can be helpful and can provide justification for effective policies and practices.

Tradeoffs between individuals and public health permeate the field of public health ethics. Where Gostin offers some key factors for consideration when deciding when to make these tradeoffs, Chadwick questions whether we have ethical tools to really understand what we 
mean when we pit individual interests against those of the collective. Chadwick uses the example of the Human Genome Project and, more specifically, biobanking to raise questions about the adequacy of the dominant ethical frameworks used to address the notion of collective interests. She considers the individualistic approach to issues in biobanking, and then discusses other ethical concepts, such as solidarity and equity. In addition, she considers the normative issues of benefit sharing, public participation, priority setting and the establishment of a collective identity.

Chadwick argues that biobanks in particular are, or ought to be, precipitating new concern over group interests, as opposed to concern over issues arising from individualistic medical ethics-reliance on the individual choice model alone is likely to be inadequate. The Human Genome Project may necessitate new paradigms in ethics, whether or not we believe that there is a difference in kind between genetics and other kinds of medicine.

What Chadwick calls the "standard view" is the dominant bioethical framework that is based on autonomy and choice. Every ethical theory has a conceptualization of the individual moral agent and about individual choice, whether it be in relation to maximizing good, fulfilling duties, etc. In reference to genetics, then, ethics can help us understand what might be required to make informed choices, but ethics can also help us understand possible implications for personal identity. Chadwick argues that ethics can not only help us think about what is right and wrong when it comes to genetics, but that genetics can also change our view about what is ethically acceptable.

Insofar as genetic information pertains not only to the self, but to genetic relatives, it is not helpful to have an individualistic notion of choice because, she argues, "we make choices not only as individuals, but also as members of a number of different groups." This is important when it comes to looking at collective goods. She asks: What ethical resources should we be using in addressing the issues of genetics databases? Ought community interests take precedence over individualistic ones?

The principles of solidarity and equity are offered as different axioms from the individualistic ones considered earlier in the paper. She identifies democratic engagement as an issue that has recently become more prevalent, in part because biobanking, among other issues, forces us to consider what things could be considered common interests. One question that arises from this is whether public participation in decisionmaking can foster a sense of collective identity that is not merely an aggregation of individual interests or preferences. This leads her to conclude that shifting our ethical lens away from the individual and towards the community may be a necessary but insufficient means of identifying the "sources of collective identity that are at stake" when it comes to biobanking.

We need look no further than to Benatar's paper to see how impoverished our sense of collective identity is. He begins by showing empirical evidence for our lack of moral consideration for others and by demonstrating that progress and globalization have benefited only a small number of people. This, coupled with the emergence of new pandemics, leads him to conclude that we are either living in an amoral world at best, or a morally depraved one at worst. Benatar outlines the dominant values that have shaped our world, and attempts to show how a broader definition of public health is more consistent with a global ethic for health. His paper attempts to persuade us of the moral importance of extending moral considerability to those who lie beyond national and economic borders. One could say, following Jennings' lead, that Benatar's critical ethics gives rise to 
his plea for advocacy. Indeed, his paper concludes with some suggestions for how doctors can become better advocates for the public's health.

One of the crucial distinctions drawn in Benatar's paper is between what he calls 'upstream' and 'downstream' sources of health disparities. A broader definition of public health would include the social, political and economic determinants of health, and would allow for consideration of upstream, or root, causes in health inequities. Not only would the inclusion of these factors allow for the development of models of health that have more explanatory power, but they force us away from traditional bioethics' engrossment with the individual, human rights and interpersonal relationships. The deficiencies of human rights discourses and parochial perspectives in addressing global social injustice are clear, and potentially impede, the development of a global social contract. He argues for the expansion of the human rights discourse so that it includes social, economic, cultural and economic rights, as well as corresponding duties that obtain at the level of individuals and nations.

Central to Benatar's project is the promotion of particular values-the most obvious one being the common good. Solidarity is an important value as well. Self-interest, common interest and identity all play a part in how we conceive of solidarity. He argues that although solidarity may be a difficult value to define and a difficult state to achieve, this does not diminish its importance. Finally, he argues for greater attention to be paid to enlightened, long-term self-interest as a motivating factor for the development of a "global mindset in heath ethics." He argues this because he would not suggest that the rationale for this mindset be based solely on altruism.

This raises an interesting point. Altruism implies acting in a supererogatory manner, i.e. going beyond the call of duty. At the other end of the moral spectrum we find ethical egoism, of which enlightened self-interest is a form. Perhaps arguing for a global ethic, such as the one Benatar describes, could be done on deontological grounds, thereby relying neither on altruism nor upon the more base ethical egoism. For one important question, in terms of public health advocacy, is whether or not it is wise to advocate for the common good by appealing to people's sense of enlightened selfinterest, despite the fact that it is surely the most pragmatic approach to advocacy. For if we have as our ultimate objective the expansion of people's realms of moral consideration so that they extend beyond their current bounds, then surely appealing to enlightened self-interest would not necessarily further this end-it could even undermine it in the long run. Benatar is right, however, to note that there has been a dearth of attention paid to the duties and responsibilities that correspond to human rights, thus making talk of respect for all persons in the context of community difficult.

\section{Conclusion}

Our symposium highlighted the fact that public health ethics is characterized by complexity and uncertainty. There is always a set of potential conflicts in public health and hence the need for balance between such things as collective and personal good, coercion and duty to care, scientific uncertainty and necessity for action.

Future scholarship and research is required, particularly on the conceptual and theoretical basis of public health ethics. Empirical case studies are required in order to evaluate the diversity of issues and practices specific to public health ethics. These should illuminate all dimensions of public health deliberation, local, national and global.

For public health ethics to mature as a dis- 
cipline requires capacity-building with specific attention to curriculum development and funding for research and development. Currently, public health ethics is poorly represented on the course curricula of schools of public health, though this will change in the near future. A model curriculum has been developed in the United States(11) and the University of Toronto commenced a course in public health ethics in 2003. Finally, the use of moral imagination, and demonstration of courage in the need to change an inequitable global landscape should motivate public health ethics beyond a merely academic exercise.

\section{Acknowledgement}

The authors would like to acknowledge the contributions of the Public Health Ethics Interest Group: Solly Benatar, Abdallah Daar, Elaine Power, Jackie Smith, and Martin Sommerfeld, Department of Public Health Sciences \& Joint Centre for Bioethics, University of Toronto. In addition, we would like to acknowledge the generous financial support the symposium received from: the University of Toronto Department of Public Health Sciences \& Joint Centre for Bioethics; the Connaught Fund for International Symposia; and The Canadian Institutes for Health Research, Institute of Population and Public Health.

\section{References}

1. Beauchamp D. Public Health as Social Justice. Inquiry 1976; 13: 3-13.

2. Szreter S. The importance of social intervention in Britain's mortality decline. Society for Social History of Medicine 1988;1(1):1-41.

3. Beauchamp DE, Steinbock B, eds. New ethics for the public's health. New York: Oxford University Press; 1999.

4. O'Neill O. Public Health or Clinical Ethics: Thinking beyond Borders. Ethics \& International Affairs 2002; 16 (2).

5. Callahan D, Jennings B. Ethics and Public Health: Forging a Strong Relationship. AJPH 2002;92 (2): 169-76.

6. Gostin L. Public Health, Ethics, and Human Rights: A Tribute to the Late John Mann. Journal of Law, Medicine and Ethics 2001; 29: 121-30.

7. Gostin L, ed. Public Health Law and Ethics. Berkeley: University of California Press; 2002.

8. Schabas R. Is Public Health Ethical? CJPH 2002; 93(2): 98-9.

9. Upshur R. Principles for the Justification of Public Health Intervention. CJPH 2002; 93 (2): 101-3.

10. National Advisory Committee on SARS and Public Health. Renewal of Public Health in Canada: Her Majesty the Queen in Right of Canada 2003; Report №. 1210.

11. Association of Schools of Public Health. Ethics and public health: model curriculum; 2001-2003. 